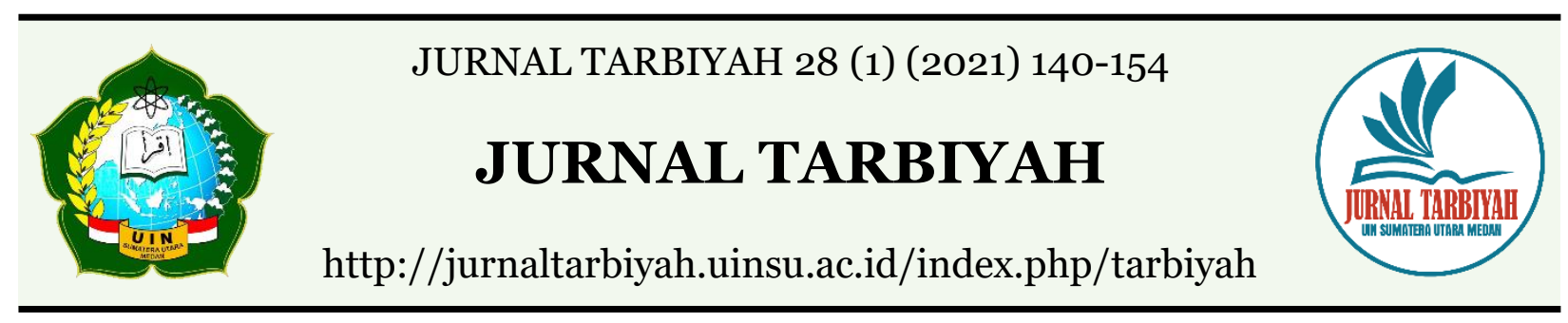

\title{
MAKING SIMPLE HYDROPONICS TO IMPROVE STUDENTS' SCIENCE-PROCESS SKILLS IN PGSD DEPARTMENT FKIP UMSU
}

\author{
Indah Pratiwi', Chairunnisa Amelia ${ }^{2}$, Karina Wanda3 \\ 1,2,3 Universitas Muhammadiyah Sumatera Utara, Medan, Indonesia \\ Email: ${ }^{1}$ indahpratiwi@umsu.ac.id , ${ }^{2}$ chairunnisaamelia@umsu.ac.id, \\ 3 karinawanda@umsu.ac.id
}

DOI : 10.30829/tar.v28i1.981

Accepted: March 14th, 2021. Approved: June 28th, 2021. Published: June 30th, 2021

\begin{abstract}
This study aims to determine the process of planting and growing mustard bok choy through hydroponics. Hydroponics is a system of cultivating plants without using soil as a medium for growing plants. Provision of nutrients needed for hydroponic cultivation of plants, essential nutrients both macro, and micro. Bok choy is a plant that has high economic value. The planting of bok choy mustard is carried out in Tanjung Balai City, Teluk Nibung District, Struggle Village. The process of planting mustard bok choy is carried out in the area where the researcher lives in June due to the impact of the COVID19 pandemic. The time for planting mustard bok choy is carried out for approximately 40 days until the harvest. The interaction between the concentration of nutrients and the type of mustard affects the growth of mustard bok choy. The nutrients used for planting mustard bok choy are $\mathrm{AB}$ Mix nutrients. This study showed that the concentration of $\mathrm{AB}$ Mix nutrients given to the growth of mustard bok choy grew hydroponically.
\end{abstract}

Keywords: Hydroponics, Planting Media, Plant Cultivation 


\section{INTRODUCTION}

The curriculum in every educational institution, significantly higher education institutions, science education, is one of the general subjects found in the Elementary School Teacher Education (PGSD) study program. It is intended that university graduates and graduate competence in their fields also have creativity in creating exciting and fun learning processes. FKIP UMSU students need to be equipped to create science learning media in the Basic Concepts course to be meaningful in the learning process. The purpose of compiling learning media for science education is so that students can increase their creativity in making learning more exciting and easy to understand.

Supporting facilities in science education courses is necessary for helping to achieve effective learning outcomes. These facilities include learning media and science practicum. The results of initial observations that learning media or science practicum are necessary for the learning process can increase student creativity. The use of learning media and science practicum in the learning process in groups helps the group learn critically and emphasizes increasing student creativity towards the given learning media, which will enable students to make these media.

Learning theory and implementing teaching and learning activities prove that an educator has to change the old paradigm. Educators need to organize and carry out teaching and learning activities based on the following points: (1) knowledge is discovered, formed, and developed by students, (2) students actively build knowledge, (3) educators need to try to develop student competencies and abilities, (4) education is a personal interaction between students and interaction between teachers and students.

Currently, the object of scientific study is becoming more expansive, covering science concepts, processes, scientific values and attitudes, science applications in everyday life, and creativity (Kemendiknas in Purwanto, 2011:11). The learning process of Basic Science Concepts must emphasize the provision of direct experience by students to develop competencies to explore and understand the natural surroundings, which in the end, they find themselves the concept of the subject matter they are studying.

For the success of learning that uses groups such as science learning media, creativity is needed among students. Creativity is the potential of every human being and not what is received from outside the individual. Human creativity is born with the birth of the human being. Since birth, the individual has shown a tendency to actualize himself. In this life, creativity is essential because creativity is a significant ability in human life. It must be admitted that it is not easy to determine an operational definition of creativity 
because creativity is a multidimensional and plural concept, so many experts have put forward the definition of creativity. According to Barron, quoted from Ngalimun et al. (2013: 44), creativity is defined as the ability to create something new.

Utami Munandar (2011: 29) provides the following limitations; creativity is the ability to create new combinations based on existing data, information, or elements. In this case, Munandar means that creativity does not need to create new things but is a combination (combination) of things that already exist. Meanwhile, data, information, or existing elements refer to a person's experiences in his life, including knowledge. Therefore, all experiences allow one to create, namely by combining (combining) the elements into something new.

Creativity (creative thinking or divergent thinking) is the ability to be creative based on available data or information in finding many possible answers to a problem, where the emphasis is on quantity, efficiency, and variety of answers. The answers given must be following the problems faced by paying attention to the quality and quality of the answers. Creative thinking in answering all problems is showing fluency in thinking (can give many answers), showing flexibility in thinking (flexibility), giving varied answers, and seeing a problem from various points of view. Operationally, creativity can be formulated as "the ability that reflects fluency, flexibility (flexibility), and originality in thinking, as well as the ability to elaborate (develop, enrich, detail) an idea.

Creativity is a thought process that leads someone to find new methods and ways to solve a problem. Then he found that the important thing is not what is produced from the process but what is important is the fun and excitement seen in doing creative activities. Based on the previous description, it can be concluded that creativity is a smooth, flexible and original thought process in creating an idea that is unique, different, original, new, beautiful, efficient, and meaningful, and leads someone to try to find new methods and ways to solve problems.

The descriptions above can be stated that creativity is essentially a person's ability to give birth to something new, either in the form of ideas or real works, the form of new works or a combination of things that already exist, all of which are relatively different from what has been done before.

This research aims to improve science process skills to become a better direction in recognizing plant cultivation, namely by making simple hydroponics at home. It is done so that students also practice directly on the plants around them to be cultivated. 


\section{LITERATURE REVIEW}

Indonesia has various plants that have benefits or are suitable for consumption, including mustard greens, spinach, kale, etc. However, with the rapid population growth and high economic level, many forests that were once green and thrived became a place for plantations and uncontrolled settlements. God willing, planting plants using a hydroponic system can reduce deforestation and improve people's quality of life because this hydroponic system does not use chemicals. Hydroponics (English: hydroponic) comes from the Greek words hydro which means water, and ponos, which means power. Hydroponics is also known as soilless culture or plant cultivation without soil. So hydroponics means cultivating plants that utilize water and without using soil as a planting medium or is soilless. Hydroponic techniques are mostly done on a small scale as a hobby among the people of Indonesia. The choice of plant species to be cultivated for a commercial scale must be considered.

Hydroponics is a method of growing without using soil media but using water and various nutrients needed by plants. Hydroponic cultivation is developing well because it has thin soil that can be planted more plants than it should. The success of plants to grow and produce is more secure. Plant maintenance is more practical; water and fertilizer use are more efficient because they can be reused; plants die quickly to replace with new plants, do not require much labor, and are undoubtedly healthier because they do not use harmful chemicals. While the disadvantages of hydroponics are: the initial investment cost is more expensive, the concentration is very influential, and the nutrient composition is not excessive.

Hydroponics is one of the future agricultural systems because it can be cultivated in various places, whether in villages, in cities, in open fields, or even above apartments. Narrow land area, critical soil conditions, uncontrollable pests and diseases, limited irrigation water, uncertain seasons, and non-uniform quality can be overcome with a hydroponic system. Horticultural commodities that are often cultivated with a hydroponic system are vegetable crops, one of which is bok choy. Bok choy (Brassica rapa L.) is a leaf vegetable plant belonging to the same genus as mustard greens. Bok choy is a short-lived plant that contains nutrients. Bok choy is a plant that has high economic value. Bok choy plants can grow in the highlands and lowlands. The use of a hydroponic system is expected to increase the growth and yield of bok choy plants. Therefore, research is needed on the types of planting media and types of nutrients on the growth of bok choy hydroponic systems. 
The hydroponic cultivation system is the cultivation of plants without using soil as a plant medium with nutrients for growth. Narrow land area, critical soil conditions, uncontrolled pests and diseases, limited irrigation water, uncertain seasons, and nonuniform quality can be overcome with a hydroponic system. Hydroponics can be cultivated throughout the year regardless of the season. Maintenance of hydroponic plants is also easier because the cultivation area is relatively clean, the planting media is sterile, plants are protected from rain, pests and diseases are relatively small, and plants are healthier and have higher productivity. The basic principles of hydroponics are divided into two, namely, substrate hydroponics and NFT (Nutrient Film) techniques. One type of hydroponic substrate is the wick system. The Wick system is the most straightforward hydroponic system. In principle, this axis system only requires an axis that can connect the nutrient solution in the reservoir to the growing media. Water and nutrients will reach plant roots by utilizing the capillarity of the axis (Amiira, 2015). One of the planting media that is often used in the wick system is Rockwool.

Rockwool is an inorganic medium with a granule-shaped media component that is useful for absorbing and transmitting water so that it has a high water-holding capacity that allows it to store hydroponic nutrients needed by plants to grow. The harvest period is also relatively short because after 40 days of planting, mustard greens can be harvested. The types of mustard greens are chicory (maize mustard), green mustard (salted mustard), and Huma mustard (bok choy). Mustard huma, known as bok choy (Brassicarapa L.), is a leaf vegetable with high economic value that can grow in the highlands and lowlands. Bok choy plants are short-lived plants and contain nutrients that the body needs. The content of beta-carotene in bok choy can prevent cataracts. Besides containing high beta-carotene, bok choy also contains many nutrients, including protein, vegetable fat, carbohydrates, fiber, $\mathrm{Ca}, \mathrm{Mg}, \mathrm{Fe}$, sodium, vitamin $\mathrm{A}$ and vitamin $\mathrm{C}$ (Prasetyo, 2012).

Bok choy cultivation with a hydroponic system can harvest faster. The conventional bok choy harvest is about \pm 45 days, with hydroponic being faster, about four weeks. Supporting the success of this cultivation system is a medium that is porous and well aerated and sufficient nutrients for plant growth. Fertilizer in hydroponic terms is also called nutrition. Nutrients needed by plants include macro and microelements (Perwitasari, et al., 2012). Hydroponic cultivation of leaf vegetables generally uses a nutrient solution in a standard hydroponic solution ( $\mathrm{AB}$ mix). $\mathrm{AB}$ mix is a nutrient solution consisting of stock A nutrient solution containing macronutrients and stock $\mathrm{B}$ 
containing micronutrients (Nugraha, 2014). However, the selling price is still high, making production costs also increase. As a solution to these problems, nutrient solutions can be made from organic wastes around us, which can be a source of nutrients for plants if processed correctly. One way is to ferment it using EM4. EM4 is a group of decomposing microorganisms that can convert or transform complex chemical compounds into simpler ones.

It aims to accelerate the absorption of plant nutrients. The nutrient solution as a source of water supply and nutrient minerals is an essential factor for the growth and quality of hydroponic plant yields, so it must be precise in quantity, nutrient ion composition, and temperature. These nutrients are divided into two elements: macro (C, $\mathrm{H}, \mathrm{O}, \mathrm{N}, \mathrm{P}, \mathrm{S}, \mathrm{K}, \mathrm{Ca}$, and $\mathrm{Mg}$ ) and micro (B, $\mathrm{Cl}, \mathrm{Cu}, \mathrm{Fe}, \mathrm{Mn}, \mathrm{Mo}$, and $\mathrm{Zn}$ ). The nutrient solution can be made by dissolving the fertilizer, specially formulated for hydroponic plants. The nutrients needed for Bok choy hydroponic plants to grow will be obtained from liquid organic fertilizer. Liquid organic fertilizer is a solution to the decomposition of organic materials derived from plant residues, animal, and human wastes, containing more than one nutrient element. The advantages of this organic fertilizer are that it can overcome nutrient deficiencies quickly, has no problem in nutrient leaching, and can also provide nutrients quickly (Hadisuwito, 2012). Liquid organic fertilizer is made from a mixture of goat manure, rice bran, and tofu dregs. Goat manure contains organic matter that can provide nutrients for plants through the decomposition process. This process occurs gradually by releasing simple organic matter for plant growth. Goat feces contain little water, so it is easy to decompose. In the manufacture of liquid organic fertilizer, an activator is given, namely EM4. Because EM4 contains Azotobacter sp, Lactobacillus sp, yeast, photosynthetic bacteria, and cellulose-degrading fungi (Hadisuwito, 2012). Liquid fertilizer from goat manure contains relatively more balanced nutrients than other natural fertilizers because goat manure mixes with the urine (contains nutrients); this usually does not occur in other types of manure such as cow manure (Parnata, 2011).

Hydroponics is a way of farming that utilizes water as a nutrient medium that plants will directly absorb to support plant growth. This study aimed to determine the growth response and yield of mustard plants on various compositions of growing media. Hydroponics is also a method of growing crops without using soil media, but using a nutrient solution of minerals or other materials containing nutrients such as coconut fiber, mineral fiber, sand, broken bricks, sawdust, and others substitute for soil media. In the hydroponic plants that I made, I used charcoal husk, a soil replacement medium that 
can make the mustard growth process faster and more efficient when using these media. The mustard plant is one type of vegetable plant that is currently being developed using a hydroponic system. In addition to easy maintenance, the market demand for mustard plants is also relatively high.

Mustard (Brassica juncea) is one of the horticultural crop commodities from vegetables with reasonably high nutritional content. Mustard is a type of leaf vegetable that the people of Indonesia commonly consume. Mustard plants are rich sources of vitamin A, which helps overcome vitamin A deficiency or night blindness (nyctalopia), which is currently a problem among children under five. Thus, mustard greens can help in increasing the pattern of diverse, nutritious, balanced, and safe food launched by the Ministry of Agriculture so that the quality of human resources will also increase. The utilization of narrow land and space in urban areas can be used as a place for hydroponic vegetable cultivation.

According to Parks and Murray (2011), hydroponic cultivation systems need to be provided with sufficient nutrient solutions, water, and oxygen to plant roots for good plant growth. Nugraha (2015) stated that among the factors that affect the hydroponic plant production system, the nutrient solution is one of the determining factors in determining the yield and quality of plants, especially in mustard plants. This study was conducted to determine the effect of growth and yield on plants' mustard greens using a hydroponic cultivation system.

The process of growing and growing hydroponics using water has several stages that must be done in the first stage of breaking green mustard seeds by soaking the seeds with water-soaked in onion skin. This activity is done by waiting about 3 days for the seeds to break and start growing shoots. If it has sprouted, the plant is moved to a place that has been prepared using water as a medium. Plants are given water and wait for 3 cows to release 4 new leaves. If these stages have been passed, the plants are given nutritional water by mixing AB Mix fertilizer. (A. Rakhman. et al, 2015).

Mustard growth is also affected by the use of seeds. The seeds to be used must be of good quality. If the mustard seeds are used from planting, it is necessary to pay attention to the quality of the seeds. For example, the plants to be taken as seeds must be more than 70 days old. Mustard greens Brassica juncea L. is an annual herb, with a single oval leaf, with a leaf length of $20-30 \mathrm{~cm}$ or more, dark green, and wrinkled. Mustard green Brassica juncea L. has broad and white prominent leaf veins. The leaf growth 
pattern is similar to that of a cabbage plant, where the leaves that appear first cover the leaves that grow later to form a white elliptical crown.

Seedling begins by placing the seeds of the bok choy plant into the planting medium, namely Rockwall. Initially, as long as I let the seeds sit for two days and two nights, the seeds were already split. In addition, after I observed its development, until now, the seedling has sprouted leaves, stems, and small roots in the Rockwool section.

After 2 to 3 leaves have appeared, they can be transferred into styrofoam prepared with clean water and MIX AB nutrient water. Next, I researched to find out the results of the bok choy plant process using Rockwool planting media and MIX AB nutrients until it was harvest time.

Products produced from hydroponics are also considered to be cleaner and look attractive compared to conventional planting products. Hydroponic cultivation activities can also be activities in the use of waste; for example, I use styrofoam in hydroponic kale growing media to contribute to waste management.

Natural Sciences (IPA) or science can be referred to as the science of nature. IPA is that studies events that occur in nature. IPA is a collection of tested theories that explain the regular patterns of carefully observed natural phenomena. IPA can also be interpreted as follows: "Science is the investigation and interpretation of events in the natural, physical environment and within our bodies". IPA is the investigation and interpretation of natural events, our physical environment, and our bodies. Like every science, Natural Sciences has apparent objects and problems, namely objects of nature and revealing the mysteries (symptoms) of nature that are systematically arranged based on experiments and observations made by humans.

Powler (Usman Samatowa, 2013: 2) states that science is a science that deals with systematic natural phenomena and objects that are arranged regularly, generally accepted in the form of a collection of observations and experiments.

\section{RESEARCH METHOD}

This research was conducted at the Muhammadiyah University of North Sumatra, located on Jalan Captain Muchtar Basri No. 3 Medan. The research will start April 2021 in class F Morning Elementary School Teacher Education Study Program.

The procedure in this study is as follows: 


\section{Problem}

An initial test was carried out to find out the existing problems. Based on the initial test given, several difficulties were encountered by the students.

\section{Planning Stage}

The action planning stage is carried out after the initial test is given. The initial test was conducted to determine the initial ability. The results of this test are then used as a reference in the learning process that will be implemented. At this action planning stage, the things that are done are:

a. Develop a learning scenario that contains the steps of activities in learning using science learning media.

b. Prepare the learning support facilities that support the implementation of actions, namely (1) teaching materials, (2) RPS, (3) SAP.

c. Students make science learning media related to science material in elementary schools in groups.

d. Preparing research instruments, (1) tests to measure initial skills, (2) conducting discussions with students who have difficulties/obstacles in completing tests, (3) observation sheets to observe teaching and learning activities (processes) carried out to see Science Process skills.

The data collection techniques used in this study were limited trials, namely documentation, observation, and tests. After the planning for the implementation of the learning process is carefully prepared, a test is given to determine the ability and skills of the student's science process before carrying out teaching activities. The teaching activities carried out are the development and implementation of the designed learning scenarios. At the end of the action, students are given a test to determine the ability to complete tests related to science material to see the results achieved by students after giving the action.

Giving action is done by teaching students to improve students' science process skills in a class by making simple hydroponics-observation of the implementation of the action by using the observation sheet that has been made. The lecturer who served as an observer filled out the observation sheet to see the teaching and learning conditions in the classroom had been carried out according to the teaching program when the action was taken and as an implementation process to see how far this simple hydroponic making could improve students' science process skills. 
The data analysis technique is by making data reduction, selecting, determining focus, simplifying, summarizing, and changing the form of raw data in field notes. After being reduced, the data is ready to be presented, meaning that the analysis stage comes to the presentation of the data. The data obtained from the initial test and the final test were processed to determine the scores obtained by students so that it was known the Percentage of Earnings Results (PPH) per student. For the Percentage of Gaining Results $(\mathrm{PPH})$ from the student problem-solving ability test, the following formula is used:

$$
\begin{aligned}
& \mathrm{PPH}=\frac{\text { Student Score }}{\text { Maximum Score }} \times 100 \% \\
& \text { (Sutomo, 1985) }
\end{aligned}
$$

The student ability level to complete the test is determined by the criteria for determining the level of student mastery of the material being taught according to the following criteria:

The conversion used in converting raw scores into standard scores with absolute norms is based on the mastery level of the given material. The level of mastery will be reflected in the high and low raw scores achieved.

The guidelines used in determining the level of student mastery are as follows:

The Five Absolute Norms Skala

\begin{tabular}{|c|c|}
\hline Mastery level & Category \\
\hline $90 \%-100 \%$ & Very high \\
\hline $80 \%-89 \%$ & High \\
\hline $65 \%-79 \%$ & Medium \\
\hline $55 \%-64 \%$ & Low \\
\hline $0 \%-54 \%$ & Very low \\
\hline
\end{tabular}

Then the determination of student learning mastery classically can be determined using the formula:

$$
\text { PKK }=\frac{\text { Number of } \text { students who got } P P H \geq 65 \%}{\text { Total of } \text { Research Participant }} \times 100 \%
$$

Explanation:

PKK : Percentage of Classical Completeness 
Based on the criteria for mastery learning, if the class has reached $85 \%$ of students with $\mathrm{PPH}$, then classical learning completeness has been achieved.

\section{RESULTS}

The research results on making simple hydroponics to improve science process skills by PGSD students have been carried out in the context of collecting and processing data.

From the initial tests carried out, it can be seen how far PGSD students are able to make simple hydrophobics and understand science process skills in developing science courses for PGSD students. The making of simple hydroponics by each student is completed in 2 processes, where the previous student has designed the hydroponic that will be made and completes the hydroponic that has been designed complete with the plants and explains the development of the hydroponic plant every day online learning.

Students send the development of hydroponic plants made in photos and videos explaining the media they have made. It is done to find out how many science-learningprocess skills students have even online.

The results of this research by making simple hydroponics, it was found that the assessment of students' science process skills before and after using hydroponics as a learning aid was as follows:

\begin{tabular}{|c|l|c|c|c|}
\hline No. & \multicolumn{1}{|c|}{ Indicator } & $\begin{array}{c}\text { Before Using } \\
\text { Media }\end{array}$ & $\begin{array}{c}\text { After Using } \\
\text { Media }\end{array}$ & $\begin{array}{c}\text { Improved } \\
\text { Classical } \\
\text { Rating }\end{array}$ \\
\hline $\mathbf{1 .}$ & Observing Skill & $41,9 \%$ & $78,6 \%$ & $36,7 \%$ \\
\hline 2. & $\begin{array}{l}\text { Hypothesis Formulation } \\
\text { Skills }\end{array}$ & $41,9 \%$ & $80 \%$ & $38,1 \%$ \\
\hline $3 \cdot$ & $\begin{array}{l}\text { Experiment Planning } \\
\text { Skills }\end{array}$ & $43,3 \%$ & $80,9 \%$ & $37,6 \%$ \\
\hline $4 \cdot$ & Experimenting skills & $54,3 \%$ & $90,5 \%$ & $36,2 \%$ \\
\hline $5 \cdot$ & Predicting skill & $46,2 \%$ & $85,7 \%$ & $39,5 \%$ \\
\hline 7. & Skills Applying concepts & $42,4 \%$ & $79,5 \%$ & $37,3 \%$ \\
\hline 7. & Communication skills & $49,1 \%$ & $82,9 \%$ & $33,8 \%$ \\
\hline
\end{tabular}


The results obtained after and before and after Hydroponics as a learning aid do not necessarily get a high percentage overall. Some indicators need to take a long process to change each indicator. Students experience the process of change in the different learning processes in each different subject.

Based on the observations made, the concentration of $\mathrm{AB}$ Mix nutrients dramatically affects the growth of mustard greens. The process of increasing plant height at the age of 14-35 days has a high response in absorbing nutrients. At the age of 7 days, the plants were still experiencing adjustments due to the transfer from the seeding medium to the hydroponic planting medium of the Paralon system. Nutrition must be optimal to give the nutrients sufficient quantities to meet the plant's needs to get good results. If the plant is given too much nutrition, it can cause reduced vegetative development and can cause poisoning for plants. Conversely, if given too little nutrients can cause inhibition of root development, thereby interfering with plant nutrient uptake, even though the plant does not show visual symptoms of deficiency.

The results showed that the nutrient concentration treatment of $\mathrm{AB}$ Mix gave high yields of plants. It was related to the provision of the right concentration of $\mathrm{AB} \mathrm{Mix}$ nutrients for bok choy plants. The composition of macro and micronutrients is very influential on plants. Therefore, in the provision of $\mathrm{AB}$ Mix nutrition, it must be balanced according to the needs of the mustard bok choy plant.

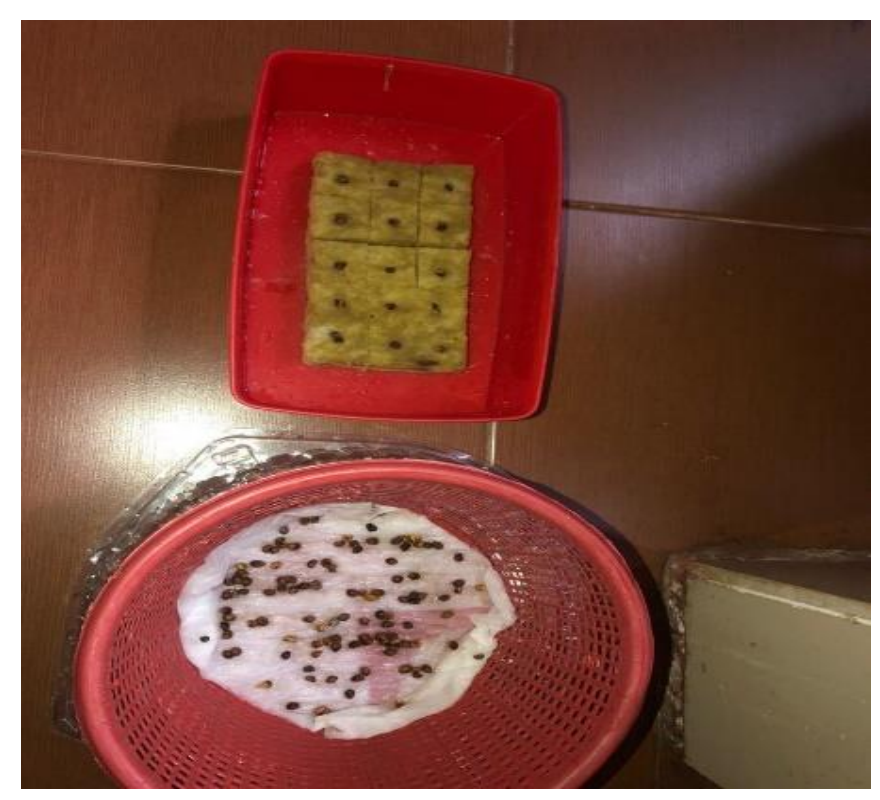

Figure 1. Day 1 of the growth of mustard bok choy which was documented by students 


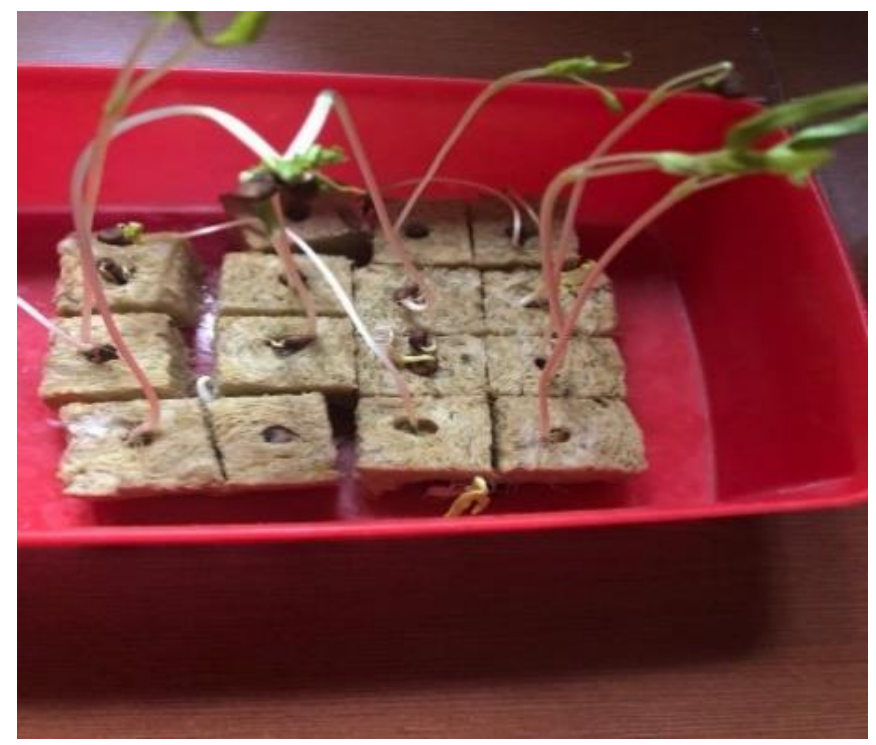

Figure 2. Day 3 of bok choy mustard seeding documented by students

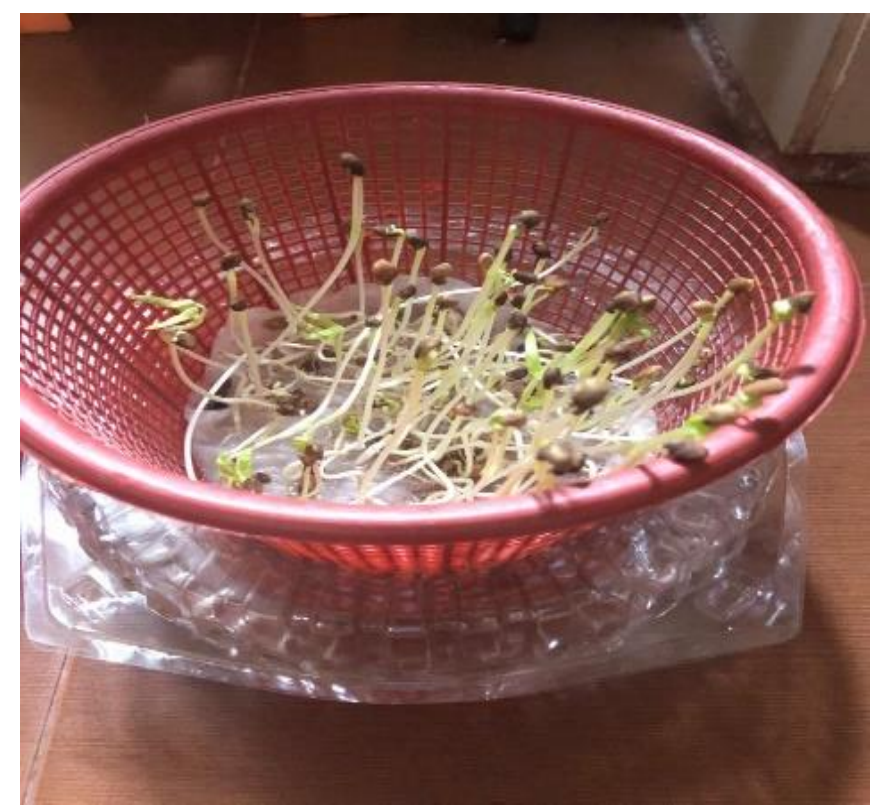

Figure 3. The 6th day of seeding Bok choy which was documented by students

\section{CONCLUSION}


From the results of the study, it can be seen that the percentage of each indicator experienced an increase in the classical assessment of the science process skills possessed by students by making simple hydroponics. In indicator 1 , the skill of observing before using the media is $41.9 \%$ and after using the media is $78.6 \%$. In indicator 2 , the skills to formulate hypotheses before using the media are $41.9 \%$ and after using the media are 80\%. In indicator 3 , the skill to plan experiments before using the media is $43.4 \%$ and after using the media is $80.9 \%$. In indicator 4 , the skill of conducting experiments before using the media is $54.3 \%$ and after using the media is $90.5 \%$. In indicator 5 , predictive skills before using the media are $46.2 \%$ and after using the media are $85.7 \%$. Then, for indicator 6 , the skills to apply concepts before using the media are $42.4 \%$ and after using the media are $79.5 \%$. Next, in indicator 7 , communication skills before using the media are $49.1 \%$ and after using the media are $82.9 \%$. From the results obtained, it can be seen that making simple hydroponics can improve science process skills in PGSD students. After this research, it is hoped that students will not only make and plant their hydroponics once because the hydroponics they make can help in terms of their income. If they can cultivate well, students can also sell their hydroponic vegetables.

\section{REFERENCES}

A.Rakhman, dkk., 2015. Pertumbuhan Tanaman Pakcoy menggunakan Sistem Hidroponik dan Akuaponik. Jurnal Teknik Pertanian Lampung Vol:4 No: 4 : 245254.

Amiira, 2015. 6 sistem hidroponik yang perlu anda ketahui. http://www.gohidroponik.com.

Aqib, Zaenal dkk. 2010. Penelitian Tindakan Kelas untuk Guru SD, SLB, dan TK. Bandung: Yrama Widya.

Arsyad. A. 2011. Media Pembelajaran (Edisi Revisi). Raja Grafindo Persada. Jakarta Hadisuwito, 2012. Membuat Pupuk Organik Cair. Penerbit Agro Media Pustaka. Jakarta Hughes, R.L. Jones,S.K. 2011. Developing and Assessing College Student Teamwork Skills. Wiley Periodicals, Inc.Published online in Wiley Online Library (wileyonlinelibrary.com)

Ngalimun,dkk.2013. Perkembangan dan Pengembangan Kreativitas. Yogyakarta: Aswaja Pressindo.

Nugraha, R. U.,(2014), Sumber Hara Sebagai Pengganti ABmixpada Budidaya Sayuran Daun Secara Hidroponik. Skripsi. Departemen Agronomi Dan Holtikultura IPB. Bogor. 
Indah Pratiwi, Chairunnisa Amelia, Karina Wanda / JURNAL TARBIYAH 28 (1) (2021) 140-154

Parks, S., C. Murray. 2011. Leafy Asean Vegetables and Their Nutrion in Hydroponics. State of New South Wales. Australian.

Parnata,A.,2011. Meningkatkan Hasil Panen Dengan Pupuk Organik. Penerbit Agro Media Pustaka, Jakarta.

Purwanto. 2011. Evaluasi Hasil Belajar. Pustaka Belajar. Yogyakarta.

Sanaky. H. AH. 2013. Media Pembelajaran Interaktif - Inovatif. Kaukaba Dipantara : Yogyakarta.

Sadiman. A.S. 2014. Media Pendidikan : Pengertian, Pengembangan dan Pemanfaatannya. Raja Grafindo Pustaka. Jakarta.

Sani, R.A. 2014. Inovasi Pembelajaran.Bumi Aksara. Jakarta.

Sanjaya, W. 2012. Strategi Pembelajaran Berorientasi Standar Proses Pendidikan. Kencana. Jakarta.

Utami Munandar, 2011. Pengembangan Kreativitas Anak Berbakat. Jakarta: Rineka Cipta.

Usman Samatowa. 2013. Pembelajaran IPA. Jakarta:Depdikbud. 